\title{
Toward a Single Law Governing the International Sale of Goods- a Comparative Study
}

\author{
W. Noel Keyes*
}

The proposed ${ }^{1}$ Uniforn Commercial Code-Sales ${ }^{2}$ was drafted to nodernize the well-known and widely adopted Uniform Sales Act. ${ }^{3}$ Has this project a reasonable chance to succeed? Ought it to succeed? Would its success not inupair uniformity in this field between the United States and other countries? Ought businessnien desire its enactment state by state or by the federal government? How will its provisions affect those of the international draft and international trade in general?

*Member, New York Bar. Doctor of Laws, 1950, University of Paris. Former Collaborator at the International Institute for the Unification of Private Law, Rome, Italy. Instructor in Law, San Francisco Law School; Attorney, United States Atomic Energy Commission.

I The Uniform Commercial Code was introduced at the 1953 session of the California Legislature at the insistence of the Commissioners on Uniform State Laws and was referred to an interim committee for study under authority of the following resolution:

"REsolved By the Senate of the State of Califorma, the Assembly thereof concurring, that the interim committees of the Assembly and the Senate on the judiciary or the judicial system are hereby authorized and directed to select not less than three members of each committee to serve together as a joint study committee on the Uniform Commercial Code, and said joint study committee shall be given the power to designate interested members of the public who shall serve without compensation or expenses as an advisory committee on the code; and be it further

"Resolved, that the results of the joint study committee's consideration of the code, together with the recommendations of the advisory committee and a summary of the material presented at any public hearings which may be called, shall be presented to the interim committee of the Assembly and the Senate on the judiciary or the judicial system sufficiently in advance of the 1955 Regular Session of the Legislature so that said committees can include their recommendations on the Uniform Commercial Code in their regular reports at that session." See 29 CALIF. ST. B.J. 257 (1954).

The writer has been informed that it is contemplated that the Code will be reintroduced at the forthcoming 1955 session of the Legislature.

2 This project is called the Uniform Commercial Code—Sales. It was begun January 1, 1945 and finally approved in May 1951. Certain minor changes have been made since that date. It represents a joint work of the American Law Institute and the National Conference of Commissioners on Uniform State Laws. The chief drafters were Professors Karl Nickerson Llewellyn and Soia Mentschikoff. Their advisers included, among others, Mr. Howard L. Barkdull, Mr. Arthur L. Corbin, Mr. Willard B. Luther, Judge Thomas W. Swan, Mr. Hiram Thomas and $\mathrm{Mr}$. Sterry $\mathrm{R}$. Waterman. The article on sales is only one of six other drafts contained in the group. Hereafter it will be referred to simply as "the Code."

3 This is the American adoption of the English Sales of Goods Act of 1893. It is in force in thirty-seven states, two of the territories and in the District of Columbia. 11A U.L.A. pt. 2, table 3 (Supp. 1953). The English Act is now the law of all of Great Britain, including Scotland (with minor changes), in most of the provinces of Canada and in all the other English Dominions. See FaIConbrmge, SaIE of Goods 3. It has been in force in Califorma since August 14, 1931. CAI. Crv. CoDE $\S \S 1721-1800$. 
These and many other questions must be answered in the near future as the Commercial Code-Sales is presented to the various state legislatures. Yet perhaps it will be impossible to give a definite and simple answer. Many lawyers are wondering if there is not some other step or compromise which would neither leave us with an antiquated set of sales law rules nor so change them that the basis of uniformity both within the United States and between the English-speaking nations is destroyed. As a rule great legal changes arrive slowly among the democracies, and the period of partial chaos before their institution becomes general may undermine the certainty which businessmen continuously seek in this field of law. The business world often regards certainty in law as more important than diverse disputes on ideal justice. That is, it would regard this "certainty" as more important than what many would consider a "better law" where confusion was sure to result froin the gradual introduction of such a law.

Originally it was planned to introduce the Code simultaneously into both Congress and state legislatures. The difficulties are in part rather obvious, even assuming that the Code is a "better statute." Briefly, we can begin with the fact that in the United States, a federal statute and a state statute are not the same thing. Section 1-105 of the Code pointed out its applicability if introduced into Congress. One might believe that should a bill with this aim be a success, the whole country would henceforth be governed by a single sales statute and might forget that difficult questions of "affecting interstate commerce" would be raised in so many sales now unquestionably covered by the Uniform Sales Act. Would a businessman prefer to have a "inuch better law" for what may or may not be interstate sales and another for what may or may not be purely intrastate sales, or would he prefer a "more antiquated" but single law to govern all his sales; a law where the above "may or may nots" less often, if ever, become bothersome." Perhaps he would prefer a third solution.

In fact the section of the Code pertaining to its introduction as a bill in Congress was deleted because both the Anerican Law Institute and the National Conference of Commissioners on Umiform State laws felt that their functions were primarily in the field of state rather than federal law. Section 1-105 now makes the Commercial Code-Sales applicable to a contract which has any of the enumerated contacts within a state which has adopted the Code. Thus it applies to any contract or transaction "made, offered or accepted" or "to be performed or conipleted wholly or in part"

4 The problems do not end here. However, if the Code were adopted by the federal government, the states could end the conflict by also adopting it at the same time-although if the states were to adopt the Code it would appear to be unnecessary for the federal government to do so.

5 This information was communicated to the writer by Mr. Martin J. Dinkelspiel, former chairman, National Conference of Counmissioners on Uniform State Laws. 
within such state, as well as to any contract which "relates to or involves goods which are to be or are in fact delivered, shipped or received" within such state. The present wording represents an attempt on the part of the drafters to extend the applicability of the Code beyond that resulting from the application of normal conflict of law rules. It would appear that the drafters ignored the fact that one of the ends of conflict of laws principles has been termed the achievement of uniformity of result regardless of the civilized forum before which the action is brought. A court in a jurisdiction which had adopted the Uniform Sales Act may find it more desirable to apply that statute where most of the above-mentioned contacts occurred within the state regardless of the fact that one or more of these contacts (viz., the offer or the shipment) occurred in another state which has enacted the Code-notwithstanding the knowledge of the court that, were suit brought in the latter state, an opposite result might be reached by applying the Code. The court in the Code state is prevented from using the Uniform Sales Act by application of normal conflict of laws principles. This section of the Code could be tempered to grant more freedon to the adopting state to employ its conflict rules and thus permit its courts (which must choose whether a contract is to be interpreted in the light of a foreign or domestic statute) to rest secure in the belief that the same result would probably be reached regardless of where the action were brought. Foreign tribunals may consider this section of the Code as representing a rather narrow or provincial tendency on the part of the adopting states of the United States. It is felt that the comity granted by applying the laws of other countries where substantial contacts occur in the process of making a sale is preferable to showing possible disrespect by putting these countries on notice that our states will apply domestic law even though most of such contacts occur in the foreign jurisdiction. ${ }^{6}$ This provision of the Code appears to be a step backward in the development of the law. One more respectful approach toward the end sought by the Code's drafters would be to seek agreement on the part of the United States and commercially im-

${ }^{6}$ The California cases have recognized the doctrine of comity. Estate of Henning, $128 \mathrm{Cal}$. 214, 220, 60 Pac. 762, 764 (1900). Alaska Packers Assn. v. Industrial Accident Comm., 1 Cal.2d 250, 34 P.2d 716 (1934).

The only apparent remedy for this situation under the provisions of the Code is for the parties to agree that the law of one state or nation shall govern their rights and duties. This is permissible under the Code where the contract "bears a reasonable relationship to one or more states or nations" in addition to the state adopting the Code. §1-105(6). Adoption by the latter would, of course, extend the common law jurisdiction of the federal government to the realms of both interstate and international sales. Its adoption by both the federal and state governments would considerably simplify international conflict of laws questions which are often the headache of the private international lawyer. However, its adoption by either of these respective governments alone would only serve to complicate conflict of laws questions. This will be treated later in the article. 
portant foreign nations with regard to a common statute applicable to all sales of goods between them.

In the international sphere, which is daily becoming more important, it must not be forgotten that the other English-speaking nations or large political divisions thereof (and there are at least twenty-seven of these, without counting the states of this country, all commercially very active countries), have incorporated the British Sales of Goods Act into their law with little variation. The Uniform Sales Act (the American adoption of the British statute) has been almost universally adopted in the Umited States. Thus, with America included, more than one-half of the most commercial part of the world is governed by the words of a single sales law. These other countries have to date manifested little intention of modifying their laws in favor of an American "better draft." This might well be the greatest argnment against the proposed American improvement, for upon reading the Code it is obvious that the Commissioners on Uniform State Laws and The American Law Institute have given little or no thought toward this now present unity. ${ }^{7}$ Even should the Canadians, for example, prove willing to consider it, can it be expected that the legislatures of Great Britain, New Zealand, Barbados, South and Western Australia, Victoria, Tasmania, Queensland, etc., would rush to do so?

Of course this uniformity of sales laws is limited to the English-speaking countries and does not include continental Europe or its colonies nor any of the Latin American republics. These two great blocs of countries cannot be united internally with the English-speaking countries with respect to a common law of sales without the greatest difficulty. The difficulty is due to some rather fundaniental differences between countries deriving their law primarily from Justinian and the ancient Romans and those whose system of law was based on the English common law. ${ }^{8} \mathrm{~A}$ business-

7 See 63 HaRv. L. REv. 561, 563, 564 (1950) where Professor Williston noted that, "[T]he existing Sales Act ... was based on the English Sale of Goods Act .... Moreover, the extensive commerce of England with South America and elsewhere has made the English Sale of Goods Act the recognized statement of the common law, as distinguished from the civil law. The wide enactment in the United States of the Uniform Sales Act, identical in most respects with the British Act, has strengthened this assumption .... When the American Act was drafted it was thought to be of considerable advantage that the statute so closely resembled the English statute. This advantage has subsequently been increased by the wide adoption of the English statute, especially in the provinces of Canada. It is surprising, when the scope of the world is now narrowed by increased speed of transportation, and when there is an earnest desire for foreign commerce, that the advantage of similarity to the English law should be so hightly cast aside."

8 The differences between the two great systems of the Occident are many. It appears to this writer that they are in large part differences of approach rather than those affecting net results. However, the following fall into the latter category:

1. Specific performance is a normal remedy of the buyer for non-delivery. In France, for example, it has been noted that "the obligee, without question, has the right to require specific performance of a contract; he must only act in good faith in accordance with the 
man might ask "should we sacrifice an existing (if only English-speaking) international umity in favor of a locally 'much better sales law'?" Should not any revision try to increase existing unity by trying to bring Europe and South America into the private legal fold in this realn of commerce? If this is not possible internally, perhaps it might at least be done with respect to international sales. Again, he might ask, "is not a solution possible here?"

Under our Federal Constitution, foreign conmerce is within the province of federal enactments ${ }^{9}$ and were Congress to pass a law governing the international sale of goods, it might apply to all private sales and purchases in our foreign trade. As regards international sales, such a statute would be of little improvement over a uniform law adopted by the various states unless a similar statute were also adopted by countries with whom the United States carries on a large part of its foreign trade. Were the Uniform Commercial Code to be enacted by many states in this country, we are left with at least three general legal groups as regards sales laws: (1) those states of the United States which have enacted the Code, (2) Englishspeaking countries and states of the United States which are governed by a statute similar to the Uniforn Sales Act, and (3) the civil law countries of Europe, Central and South America and of the near and far East. Although various countries or states within each of these groups are continuously refining their own laws pertaining to sales, no concerted attempt is being made in this country to unify the sales law applicable to trade between the countries making up these groups by the expedient of enacting a single statute to govern with respect to such trade.

UNIDROIT-THE DRAFT OF A UNTFORM LAW ON THE INTERNATIONAI SALE OF MOVABLE GOODS

Thus far we have always considered the Code a definitely "better law" on sales as compared with the Uniform Sales Act. Such a consideration nuay

terms of Article 1134(3)." Planiol-Ripert, Traité élémentaire du Droit Civil (1943), p. 530. In the Anglo-American system, the normal recovery is for damages, and specific performance is only allowed "extraordinarily," as for example where the goods are unique or damages are insufficient.

2. Continental buyers must, in principle, denounce (mettre en demeure) a seller for nonperformance before an action may be commenced against him. (See Article 1139 of the French Civil Code.) This principle does not exist in the Anglo-American system where an action may be commenced immediately after the rupture.

3. Rules of evidence, particularly with regard to what a witness may say, are very elementary on the continent. For example, see Article 109 of the French Commercial Code; A comparison of English and French law and legal procedure, The Law Society 198 (1947).

4. The calculation of damages is more often made by the judge alone on the continent. Unlike the United States, the jury is rarely called upon for such service abroad.

5. The question of warranties is differently raised in civil code countries. The principle of caveat emptor does not generally exist and the remedies of the buyer are consequently more harsh on the seller than in the Anglo-American system. See Radin, Natural Lavo and Natural Rights, 59 YaIE L.J. 214, 229 (1950).

o U. S. Const. Art. I, \& 8. 
be no exaggeration with regard to purely domestic sales, although to demonstrate this would require a detailed examination and comparison section by section. The drafters have aided us to some extent in the commentary following each section of the Code. However, to the writer's knowledge, they have made no international comparative study of the world's various sales laws or projects in order to aid them in drafting the code. ${ }^{10}$ The value of such a study has been hailed by many. An eminent Scottish jurist (who sits somewhat astride the two systems) has stated that "more references to the civil law are to be found in leading judgments on the law of sale than perhaps any other single chapter of the common law." 11

One study which could have been made concerns the draft of a Uniform Law on the International Sale of Movable Goods. This project was drawn up between 1929 and 1935 by the International Institute for the Unification of Private Law situated in Rome, Italy. ${ }^{12}$ During this period the Institute was maintaining close relations with the League of Nations, and in 1935 this draft was transmitted to the League's Council, which decided to send it to all states, including those who were not menbers. The draft was well received by most of the governments. Only Great Britain, India, Poland and Yugoslavia declared that the need of unification was not felt in their countries. The Benelux countries made many useful remarks and the governments of the four Scandinavian countries appointed a special commission which elaborated a series of suggestions. Thereafter, the project was modified and the revision was completed in 1939 when the war interrupted further progress. However, the project recently has been receiving more attention both here and abroad and a diplomatic conference held at the Hague in 1951 set up a special commission to further study it. ${ }^{13}$

This project, which will hereafter be referred to as "Unidroit," 14 was not drafted to be the internal law of any particular country or of a political division of such country, as for example a state of the United States. There-

${ }^{10}$ The writer was informed in 1950 by Professor K. N. Llewellyn that the Code drafters undertook no study of foreign sales laws.

11 Macktytosh, The Roman Law of Sale VI (2d ed. 1907).

12 The drafting committee of the Institute was composed of the following eminent jurists: Algot Bagge (Sweden), Henri Capitant (France), Martin Fehr (Sweden), H. C. Gutteridge (England) and Ernst Rabel (Germany). "In this way we assured the representation of the four principal judicial systems interested in any plan of unification; that is, the Anglo-American, Latin, Germanic and Scandinavian system ...." Etudes du Droit Civil a la Mémoire de Henri Capitant 280 (1939).

13 Lagergren, Delivery of the Goods and Transfer of Property and Risk in the Law OP SALE, Stockholm (1954).

14 "Umidroit" is the cable name of the International Institute for the Unification of Private Law, via Panisperna 28, Rome, Italy. It means simply "uniform law" and it is used in this article to replace "The Draft of a Uniform Law on the International Sale of Moveable Goods." Copies of this draft may be obtained froin the Institute. 
fore, there would be almost no conflict between Unidroit and the Code should both be enacted simultaneously. One would simply complement the other by covering the field of international sales now subject to the state or foreign national law which is determined in accordance with conflict of laws principles and the legal consequences of "adhesion" contracts" neither of which can businessmen be expected fully to understand. ${ }^{16}$ Since the first World War, importers and bankers have complained of the lack of cohesion in the field. Some of these were over-delighted with the coming of the Code because of its "inclusion of international trade." That is, they believed that it would be introduced as a federal statute ${ }^{17}$ on the theory that the Code could have a greater influence on international commerce than if it were enacted state by state. Logically, these men should receive and promulgate Unidroit, which is the only draft which in any way would unify sales law with respect to international sales, and bridges the gap between the common law and civil law countries. ${ }^{18}$

If Unidroit is more important than any existing draft as regards international trade, certainly it deserves more attention. Unlike the Code, Umdroit has the advantage of not conflicting with any other statute in the field of international sales: no other statute of importance exists. The result of its general enactment would be the unification of the sales laws of the world with regard to international sales. However, we should ask, before striving for its enactment, "does Unidroit represent a good, up-to-date draft international sales law?" An attempt will here be made to point out some answers to this question by examining Unidroit and nuaking compari-

$15 \mathrm{~A}$ discussion of the origin of this term is found in Ehrenzweig, Adhesion Contracts in the Conflict of Laws, 53 Cor. L. REv. 1072, 1075 n.17 (1953).

10 There was a question whether Unidroit should be based upon the written laws and cases in force in the principal countries of the world or rather on the above mentioned adhesion contracts. The former solution was chosen exclusively because of the lack of uniformity among the adhesion contract forms of different industries. Gutteridge, Etudes du Droit Civil a la Ménoire de Henri Capitant 273 (1939); Rabel, The Conflict of Laws, A Comparative Study 482 (1947); S.d.N.-U.D.P. 1929-Études; LV-Vente-Dec. 1.

17 Ward and Rosenthal, The Need for the Uniform Commercial Code in Foreign Trade, 63 HARV. L. REv. 589, 592 (1950): "A new Code will establish a firm legal foundation, based on modern international trade conditions, on which lawyer and international trader can proceed with safety and certainty. As to those who have drafted the Code, they have studied the precedents in law and in practice over the years. The best and most sound of these are included in the current revision of the Code. The inclusion of international trade in a Uniform Commercial Code will provide export and import transactions with a pattern in which the business man can operate properly and safely and in which business can flow with far more certainty than would be the case if the expedient had been adopted of piecemeal revision of its various components."

18 Here is meant, for example, all the countries of continental Europe and South America. In France, the laws applicable to sales are divided between the Code Civil and the Code Commercial. In Italy such separate codes bave recently been combined into the Codice Civile. 
sons with the Uniform Sales Act and the "final draft" revision of that Act: The Commercial Code-Sales. ${ }^{19}$

\section{What is Not Covered by Unidroit}

Unidroit is at least as extensive as the Uniform Sales Act but much shorter than the Code. For example, Unidroit contains nothing on the formation of contracts. ${ }^{20}$ Article 11 (a) limits Unidroit to "the obligation of the buyer and the seller arising from a contract, which contract is valid according to the principles of private international law." It does not state what will be the rule of conflict of laws applicable, and therefore questions concerning the formation of contracts must be resolved under the rules of conflict of laws of different states or different countries. ${ }^{21}$ The same is true with respect to international sales and purchases of goods between a civil law country and a common law country which has adopted either the Umform Sales Act or the Uniform Commercial Code-Sales.

Neither Unidroit nor the Uniform Sales Act makes any distinction between civil and commercial sales. ${ }^{22}$ There is at present a tendency away from this distinction on the European continent where Italy, for example, has completely abolished its former commercial code (Codice Commerciale) as a separate entity. Therefore, it was astonishing to find that the drafters of the Code wished to introduce this notion into the United States for the first time in our sales law. ${ }^{23}$

19 The study which follows is based in part upon a more extensive study made by the writer wherein Unidroit was compared with the Uniform Sales Act and the draft Commercial CodeSales. This comparison was nade in 1950 for the International Institute for the Unification of Private Law, in Rone, Italy, and is written in the French language.

20 Until the last noment, the committee thought it would add a chapter which it had already drawn up on the formation of contracts. However, it finally renounced the idea and another committee was appointed to study that matter. See S.d.N. 1939 U.D.P. Project 1 (1) 53.

21 The Code on the contrary devoted four articles including nine sections to this subject (\$§ 2-204 through 2-210) which are more than are found in the Uniform Sales Act. See 11 U.L.A. pts. 1, 3 (1950).

22 See Études du Droit Civil, a la Mémoire de Henri Capitant 303-304 (1939), where Professor Hamel states that, "the international statute was drafted to govern civil sales in the same manner as commercial sales; it had been impossible to define commercial sales in an international text; the innovation would have been too great for countries which do not distinguish between commercial and civil law, and it would have been almost impossible to unify the differences ... agreement in this regard was very easily reached between members of the commission." Also see the comments of Professor Gutteridge at 282.

$23 \$ 2-104(1)$ of the Code states: "'Merchant' means a person who deals in goods of the kind or otherwise by his occupation holds himself out as having knowledge or skill peculiar to the practices or goods involved in the transaction or to whom such knowledge or skill may be attributed by his employment of an agent or broker or other intermediary who by his occupation holds himself out as having such knowledge or skill." This definition would not make our sales law nrore understandable to a man from Europe or South America. Both continents have made separate rules to govern their commercial law as opposed to their civil law. However, the commercial codes have always been considered a part of the civil codes as regards the larger and more general rules. In Europe there is a tendency to unite the two and while the divi- 
It is perhaps impossible to separate rules governing the formation of a contract from all those substantive rules concerning its existence. While in general Umidroit does not nention the former, it does do away with a rule of substantive law by stating in its Article 17 that "no particular form is required for a contract of sales." However, this language may be interpreted as doing away with the requirement of a writing. Despite many objections that have been made to the Statute of Frauds, it must be recognized that this article is against the majority opinion of the world's sales laws. ${ }^{24}$ Because of this difficulty alone, perhaps the matter should be left to the laws of the various states and nations.

\section{The International Sale}

The question "what is an international sale" was undoubtedly the most difficult which the drafters of Unidroit had to answer. They had three possible poimts of departure: an international sale would take place where

sion is still clear in France and Austria, a "mixed systein" is reigning in Germany, Switzerland, and Italy. Italy abolished her commercial code as a distinct entity in 1942.

See Transfer of Title and Risk of Loss, text infra at note 27 et seq. where the effect of this notion in the draft Commercial Code-Sales is further discussed.

${ }^{24}$ See Rabel, A Draft of an International Law of Sales, 5 U. OF CHI. L. REv. 558 (1938). Here perhaps Dr. Rabel expressed the opinion of the drafters when he stated: "How is it to be explained that soineone who has bound himself by telephomic arrangement and ounits to confirm the contract by letter, can take advantage of a statute which purports to combat fraud?" Both Dr. Rabel and Professor Williston have quoted Chief Justice Sambell in Marvin v. Wallis, $6 \mathrm{El}$ \& Bl. 726, 736 (1856): "I shall rejoice when it [section 17] is gone. In my opinion, it does more harm than good. It promotes fraud, rather than prevents it, and introduces distinctions which, I must confess, are not productive of justice." Another objection is that it is difficult for a businessman to tell when a writing is necessary. For example, in the French system, article 1341 of the Code Civil states: "All transactions exceeding 5000 francs must be in writing, and either notarized or signed by both parties ... and no testimony of witnesses may be received against or as a supplement to such a writing." Paragraph 2 adds: "This rule does not affect the rules prescribed by commercial laws." Looking in the Code de Commerce Article 109 states: "Purchases and sales may be proven by witnesses whenever the court believes such tcstimony should be admissible." Also, it has been held in France that statutes whicl deny the possibility of proving a fact by witnesses alone, can be circumvented by an oral contract of the parties agreeing to the admissibility of such proof. Civ. 8 juin 1896, D.P. 97.1.464; 6 janvier 1936, D.H. 1936. 115. Most Statutes of Frauds in English speaking countries do not allow of this possibility of by-passing the statutes.

Furthermore, the amount of money necessary in order that the Statute of Frauds be imvolved is a very changing one. This is true both as to time and to country and the political subdivisions of a country such as the United States. The Statute entered France with the Ordonnance de Moulins of 1566, 110 years before it entered England. The figure which entered the Civil Code of 1804 was 150 francs. Simce 1928 alone it has changed four times, and with the law of February 21, 1948 it was brought up to 5000 francs. In England it has remained steady for sixty-one years at \pm 10 . In the Umited States it is different in states and even where this Uniform Act is in force the figure $\$ 500$ is sometirnes changed; for example, in New York the amount is fifty dollars. Foreign businessmen can never sirnply regard the figure in the Uniform Sales Act without noticing the figure in the state adoption of that Act-which may follow the Uniform Sales Act word for word in all other important respects except this one.

The Commercial Code-Sales would continue the $\$ 500$ figure found in the Uniform Sales Act. 
(a) the contract was made while the parties were situated in different countries, (b) the goods were to pass an international border line, or (c) the contracting parties habitually resided in different countries. Other variations on these three theines were discussed. ${ }^{25}$ However, when the draft was sent to the various nations and their comments (in particular those of the Scandinavian countries) were utilized for the revised draft, all objective definitions involving the situation of the goods themselves were set aside. According to its Article 6, Unidroit was declared applicable to a contract "where the parties have their places of business or, in default thereof, their habitual residences in the territories of different countries." To answer the objection that a sale should not be considered "international" where all the formative elements of the contract occurred in one country, Article 7 was added, which makes Unidroit inapplicable "if the acts of the parties [which] constitute offer and/or acceptance or if the dispatch and reception of correspondence take place in the same country where delivery and payment are to take place." ${ }^{20}$ In this manner it was believed that Unidroit might best "take the place of the rules of conflict of laws concerning international sales and the legal norms called for by the conflict rules." 27

Of course, if Unidroit is introduced into American law by means of a treaty with other nations, it would prevail over the Code, which is merely to become a part of our internal or state statutory law. As regards any differences between them on the substantive law of sales, jurisdictional conflicts are unlikely to arise because they govern different legal spheres: the one, internal sales; the other, international sales.

${ }^{25}$ The Institute had some difficulty with this matter. Finally it adopted for the first draft, a proposition of Dr. Rabel: Article 1. "The law will be applicable where the two parties have their places of business or, in default thereof, their habitual residences in two different countries." (It would appear to the author that the word "two" could well be omitted in both places. Dr. Rabel defined habitual residence as that "in existence at the moinent when the party has transmitted his last written message concluding the contract or, where such party has concluded the contract by another act, at the moment this act is performed." However, this last part, which resembles somewhat the American draft Commercial Code-Sales, was changed when Unidroit was revised. Sir Cecil Hurst submitted several propositions concerning the transfer or transport of the goods "from one country to another where both countries are bound by Unidroit." Capitant and Hamel submitted a clause to the effect that if the parties "know that the goods are destined to be the object of international transportation, the law is applicable." They defined "international transportation" as transportation "from the territory of one state toward the territory of another state."

26 See the discussion of Professor Hamel in Etudes du Droit Civil a la Ménoire de Henri Capitant (1939) at 305.

27 "Therefore, the proposed international law is not meant as a substitute for the actual domestic law. The overwhelming majority of sales contracts remain under the same rules as they are at present. It intends to do no more than to take the place of the rules of the conflict of laws concerning sales and the legal norms called for by the conflict rules. The law thus to be applied now might be that of any foreign country, different in different cases, and difficult to apply. The proposed international law, on the other hand, would be uniform, kindred to the Sales Act, and at least intelligible." Rabel, A Draft of an International Law of Sales, 5 U. of CrI. L. Rev. 543 (1938). 
A discussion of the.substantive differences and differences of drafting technique between these proposed statutes would be an aid toward understanding them and in deciding whether or not the United States should enact a sales statute such as Unidroit which will bridge the gap between common law countries and civil law countries.

\section{Delivery and the Transfer of Title}

In drafting a sales statute something nore than a group of concepts is necessary. A central point is required around which the concepts may be pivoted in order to make the organization of the statute easily understandable.

The first of the so-called "fundamental" changes in the Code concerns the passing of title. The commentary to section 2-101 quickly gives us insight into the new position of the Commercial Code-Sales:

The legal consequences are stated as following directly from the contract and action taken under it without resorting to the idea of when property or title passed or was to pass as being the determining factor. The purpose is to avoid making practical issues between practical men turn upon the location of an intangible something, the passing of which no man can prove by evidence and to substitute for such abstractions proof of words and actions of a tangible character.

Of course it is extremely difficult to give a general definition of title which will be of considerable practical value. Yet, in spite of the quoted statement, a sale has been defined in the Code as the "passing of title" and title passes with delivery of goods..$^{28}$ Has the "law of sales" as described in the Uniform Sales Act in any way been changed by the Code as far as the question of title to the goods is concerned? Professor Williston has answered "yes" and has gone so far as to state that even though other, more minor, discrepancies be corrected, this "fundamental" change renders the enactment of the entire Commercial Code-Sales inadvisable. ${ }^{20}$

The "organization of a statute," as opposed to "the law" on the subject which it concerns, must never be confused. The Code obviously bears little relation to the Uniform Sales Act, in the former sense. However, the "law" or "proposed law" of sales as embodied in the statute and proposed statute respectively, although very different one from the other, do not appear to the writer to be fundamentally different, but only superficially so. The Uniform Sales Act is obviously pivoted about the transfer of title. ${ }^{30}$ The risk

$28 \S 2-106$.

29 Williston, The Law of Sales in the Proposed Commercial Code, 63 Harv. L. REv. 561, $565-588$ (1950).

30 Uniform Sales Act $\S 17$. This is also true in England, France and Germany where the passage of title seems to be the most determining feature in a sale. See LAGERGREN, DeLTVERY of the Goods and Transfer of Property and Risk in the Law of Sale 60 (1954). 
of loss follows the title except where a security interest is involved or there is an express clause to the contrary in the contract. ${ }^{31}$ Because businessmen (as well as lawyers) often do not know exactly what "title" means, an express clause separating title from risk is a rarity. Of course the earliest possible moment that the property in goods may be transferred is after they have been identified or appropriated. This is true of all sales laws ${ }^{32}$ and projects ${ }^{33}$ where title is an important ingredient.

Title, in the Uniforn Sales Act, is to pass according to the "intention of the parties." As was well realized by the drafters of that Act, the parties seldom discuss their intention in this regard because they do not understand its full significance. For this reason in Article 19 five rules of law were provided to "discover" this intention. If the physical transfer of the goods, their price, the risks of loss, and security interests are determined, the businessmen are satisfied. The general rule in all the statutes and projects discussed herein is that unless otherwise agreed these interests pass or are determined with delivery of the goods to the buyer. The Uniform Sales Act is no exception. The rule of intention number 4(2) of Section 19 clearly states that "where, in pursuance of a contract to sell, the seller delivers the goods to the buyer, or to a carrier or other bailee (whether named by the buyer or not) for the purpose of transmission to or holding for the buyer, lie is presunied to have unconditionally appropriated the goods to the contract ...." The further question is "does this appropriation in general constitute transfer of title." The Uniform Sales Act does not answer this in words. However, the tendency of modern sales laws is to hasten the sale of goods and thereby to "finish the sale" at the earliest possible moment and no later. ${ }^{34}$ If the moment of delivery is the moment that the goods are ap-

31 Uniform Sales Act $\S 22$. That risk of loss is assumed to follow the title in almost every case has been recently emphasized in 2 WIIIISTON, SALES $\S 301$ (1948).

$322 i d . \$ 258$ : It is obviously not enough for a present transfer of the property that the goods are so described that at some time subsequent to the bargain they will become specific. The eariest conceivable moment for transfer of the property in such a case is when the goods become identified; and generally, if not universally, the property will not pass until not only the goods are identified, but some agreed act of appropriation has taken place.

Uniform Sales Act $\S 17$; British Sales of Goods Act $\S 17$ (which section also extends to Scotland without change) and to most other English speaking countries; and Art. 1585 of the French Civil Code, followed in principle in most civil code countries.

33 See Commercial Code $\$ 2-401(1)$. While the 1949 Draft Commercial Code-Sales referred to both appropriation and identification, this was changed in the Spring, 1950 Draft in order to allow title to pass upon identification only in the absence of a specific agreement to the contrary. This is not necessarily true in Unidroit where Article 19 declares that delivery with respect to generic goods is not accomplished until they are "set aside on behalf of the buyer."

34 For example, in the Roman law the property was not transferred with delivery of the goods. Pothier, Obligations, No. 219; Mgyre, Contract of Sale in the Crvit Law, 77 (1892) ; Dig. 18, 6, 8, Si id quod venierit appareat quid quale quantum sit, sit et pretium, et pure venit, perfecta est emptio; Mackintose, The Ronan Law of Sale (1907), Periculum; Paulus Libro XXXIII ad edictun; Gaius bibro $X$ ad edictum provinciale. The French Code Civil of 
propriated or identified, this is when title passes. ${ }^{35}$ Thus we see that the things that are of most interest for the parties to a sale generally pass, or are determined, with delivery of the goods and that "title" passes with this delivery. This is as true under Section 2-401(2) of the new Code tying title to delivery as it is under rule 4(2) of Section 19 of the Uniform Sales Act. ${ }^{36}$ One can only question the value of discussing these interests via the intermediary of the word "title" as used in the Uniform Sales Act. The drafters of the Code have done no more than to put the emphasis where the real interests have always been. This accounts for the change in "organization" of the sales statute which their project is to bring about. In this connection it is noted that the Scandinavians, whose statute on sales (effective in their countries since June 20,1905) emphasizes delivery, the real pivotal interest in a sale, have considered our Uniform Sales Act an antiquated project as of the time it was first recommended by the Commissioners on Uniform Laws in 1906 and long before it was enacted by a majority of states. ${ }^{37}$

Unidroit does not discuss title ${ }^{38}$ and thus it is more simply organized and more easily understandable than either the Uniform Sales Act or the Commercial Code-Sales. Instead, it follows the lead of the Scandinavian act $^{39}$ and pivots about the notion of delivery which is accomplished "when the seller has done all the acts necessary in order that the goods may be received by the buyer or a person authorized to receive them in his behalf. The acts necessary for this purpose depend on the nature of the contract." In the case of generic goods, delivery cannot take place before the goods have been appropriated to the buyer's account and the buyer has been noti-

1804 which is in effect today, has followed the Roman law of sale very closely. However, at this point it made a decided change and Article 1138 provides that: "Consent alone may transfer to the buyer both title and risk at the moment when debivery is to be made-even though no physical act indicating appropriation (tradition) has been done."

35 See 2 WIIIISTON, SALES $\$ 278$ (1948), where only "[a]ppropriation by dehivery to a carrier" is discussed. Yet, Rule 4(2) of Article 19 of the Uniform Sales Act clearly applies in the case where the goods are delivered directly to the buyer.

30 Commercial Code $\$ 2-401(2)$ : "Unless otherwise explicitly agreed title passes to the buyer at the time and place at which the seller completes his performance with reference to the physical dehivery of the goods...."

37 Articles 9, 10, and 11 of the Scandinavian sales law which define delivery will make this clear. As regards this fundamental, the Umiform Sales Act is out-of-date not because of its positive law but because of what might be called its "positive organization of the law." It is here that the mid-nineteenth century British thinking of Mr. Benjamin (as codified by Mr. Chalmers) becomes visible. Law students for more than a century have been told "keep title in mind and the majority of sales problems will be clearly outlined." Therefore, such a change in thinking on this subject may be more difficult for the lawyers than for the businessmen. The latter will see their basic interests more clearly stated in the proposed sales law.

38 Article 5: Unidroit, "This law does not concern the effect that the contract may have on title or property in the goods."

39 See the Scandinavian Sales Law of June 20, 1905, Articles 9, 10 and 11. 
fied of this fact. ${ }^{40}$ Thus the practical effect of the Uniform Sales Act is obtained without discussing the intermediary "title." 11

The divergence of viewpoints of the various nations with respect to the transfer of title appears to this writer to be more one of form than of substance; however, with respect to international sales Unidroit completely avoids the problem and the confusion by the statement in Article 5 that, "This law does not concern the effect that the contract may have on title or property in the goods."

\section{Delivery and the Risk of Loss}

In Roman law, risk of loss passed with the consent of the parties with respect to ascertained goods. The Roman contract nerely created personal obligations and did not, like the common law contract, operate as a conveyance. This is true in German law which also separates contract and property concepts and likewise does not permit passage of property prior to actual delivery. ${ }^{42}$ However, in German law, the risk passes to the buyer upon the transfer of possession regardless of any transfer of the property. ${ }^{43}$

The maxim res periit domino, which did not apply to sales in Roman law, has led Anglo-American legal writers to thinking that risk is tied to the transfer of property in all cases worth discussing. According to this principle, risk of loss is prima facie with the person in whom the property is. As a result, while volumes are consecrated on the transfer of title, very little has been written on the transfer of risk (or at least, not under that title). On the contrary, businessmen who seldom discuss the transfer of the property, often discuss with precision the moment wlien the risks are to pass. We have, perhaps, the Uniform Sales Act to blame for this continued separation in thinking between these two coniplementary professions. ${ }^{14}$

40 See Unidroit, Articles 19, 99.

41. The Code \$ 2-106(1) states that: "A 'sale' consists in the passing of title from the seller to the buyer for a price." However, as pointed out above, this definition is not emphasized and the transfer of title is hardly further discussed in the draft, and for this reason the Code's approach resembles that of Unidroit. According to $\$ 2-401$ (1) title cannot pass before "identification" (in the 1949 draft this was "appropriation"). § 2-401(2) makes the title pass with delivery by stating "unless otherwise exphicitly agreed title passes to the buyer at the time and place at which the seller completes his performance with reference to the physical delivery of the goods ...." Unidroit, Article 19, states that: "Delivery is accomplished when the seller has done all the acts necessary in order that the goods nuay be reccived by the buyer ...." The similarity of the Code with Unidroit, Article 19 hecomes obvious if one leaves out the word title from the Code provision. If the Code were following a completely positive approach it would certainly do so. By combining the two sections, the Code could have been drafted to state: "A sale occurs at the time and place at which the seller completes his performance with respect to physical delivery of the goods."

42 See Lagergren, Delivery of the Goods and Transfer of Property and Risk in the LAW OF SALE 65 (1954).

43 Bürgerliches Gesetzbuch, § 446.

44 Uniform Sales Act $\S 22 ; 2$ Wrutrston, Sales § 301 (1948). 
Risk of loss passes with the transfer of the property and as explained above, under the Uniform Sales Act this means that, unless otherwise agreed, title passes with the delivery of the goods. Again one can only wonder concerning the value of the intermediary "title" as a simplifier in both business and legal thinking.

The Code has completely changed Section 22 of the Uniform Sales Act and according to its Section 2-509, in general, the risks are for the buyer on his receipt of the goods if the seller is a merchant; otherwise the risk passes to the buyer when delivery has been tendered to him or, where the seller is to ship the goods, when the goods lave been handed to the carrier and "in neither case does risk of loss turn on the time of delivery of documents of title." ${ }^{35}$ In this respect the Code has followed Article 99 of Unidroit according to the provisions of which the risk of loss passes with dehivery of the goods (as in effect happens with the American law and project) ${ }^{46}$ However, Unidroit nowhere distinguishes between sellers who are merchants and other sellers.

\section{Delivery and Payment of the Price}

Article 71 of Unidroit states that, "Unless otherwise provided by the contract or by the usage of the trade, delivery of the goods and payment of the price are concurrent conditions." The general rule with the Code is that "payment is due at the time ... the buyer is to receive the goods" (Sec-

45 § 2-509(1) states: "Where the contract requires or authorizes the seller to ship the goods

(a) If it does not require him to dehiver at destination, the risk of loss passes to the buyer when the goods are duly delivered to the carrier even though the shipment is under reservation; but

(b) if it does require him to deliver at destination the risk of loss passes to the buyer when the goods are there duly tendered.

"In neither case does risk of loss turn on the time of delivery of documents of title." Professor Williston has said that Subsection (1) does not necesarily mean that the goods must conform to the contract. 63 HARv. L. REv. 561, 582 (1950). However, the comment following this section is clear: "Where for any reason his delivery or tender fails to conform to the contract, the present section does not apply and the situation is governed by the provisions on effect of breach on risk of loss." $\$ 2-510$. According to $\$ 1-102$ (3) of the Code the comments may always be consulted by the court; this provision is new to California law and to that of most of the states.

40 As explained in connection with delivery, according to Article 1138 of the French Civil Code, both title and risk are transferred with the consent of the contracting parties. In the case of the risks, the Civil Code here followed the Roman law. However, Planiol has pointed out that in effect the risks in French law are transferred on or about the time of delivery: "The seller becomes bailee of the goods. The buyer maintains the risk of loss, except for his right of action against the bailee who may, by his fault, cause the goods to be lost ... . The buyer has the right to dissolve the contract should the goods by chance deteriorate, Article 1182, paragraph 3, French Civil Code; and merely by according him this option makes the risk fall back on the seller, for it is evident that the buyer will never miss using his right to dissolve the contract if the damage is of any importance." Planiol-Ripert, Traité élémentaire du Droit Civil, Tome Deuzieme (1943), $§ 502$. 
tion 2-310). Here is a modification of the Uniform Sales Act which expresses the rule set forth in Unidroit almost exactly. ${ }^{47}$

\section{Sanctions}

(a) Delay in delivery

Sections 66 and 67 of the Uniform Sales Act give the buyer at least the right to damages in every case where the goods are delivered late. For this type of case, unlike the Uniform Sales Act or Unidroit, Section 2-615 of the Code states that between merchants a delay in delivery is not a breach of his contractual duty if performance, as agreed, has been made impractical by the occurrence of an unforeseen contingency, the non-occurrence of which was a basic assumption on which the contract was made. But even in this case, if the delay is "material or indefinite," the buyer may terminate or modify the contract by a written notice to that effect. ${ }^{48}$

Of course $\mathrm{m}$ all other cases of delay (that is where a "contingency" is not involved) the buyer has an absolute right to cancel the contract. This is not the case with Unidroit, which is somewhat easier on the seller, as are the laws of most European countries. The buyer's absolute right of cancellation after a short delay in delivery (where time is not of the essence of the contract) is not well considered abroad..$^{49}$

Unidroit has followed a middle course which should be agreeable to both sides of the question. According to its Article 25, the judge cannot grant a period of grace following a late delivery; however, the seller in such a case may cancel only where time of delivery is an essential condition of the contract. Unidroit excepts from the application of this rule a contract concerning "goods having a current price on markets in whicl the seller may procure them," in which case time of delivery is deemed essential. The parties, of course, may always make the time of delivery essential to their contract at the time of contracting or even later. When the contract is declared by the buyer to be avoided and a contest arises, then the buyer carries the burden of proving that time was of the essence.

47 See $\S 42$, Uniform Sales Act. The Code conmentary explained that this position was taken in order that an opportunity to inspect the goods may always be insured to the buyer before payment. However, there is no conflict with Unidroit because Article 76 expressly states that "the buyer is bound to pay the price only after he has had an opportunity to examine the goods."

$48 \S 2-616$.

49 In continental Europe, where commercial hife is paced somewhat less rapid than over here, a delay in delivery often gives rise to a case which may be submitted to arbitration under the civil or conimercial code. The judge nuay allow the buyer to cancel or he may grant the seller a period of grace. For example, Article 1184 of the French Civil Code permits the judge to accord such a period "depending on the circumstances." However, if the parties have expressly stipulated that the contract is to be autoniatically cancelled, the intervention of the judge is to no avail; he may, if a contest arises, announce that the contract has been cancelled; but, he can neither cancel it himself nor grant a period of grace. Alger, 7 novembre 1892, D.93.2.294. 
For contracts where time of delivery is not of the essence, Article 29 of Unidroit allows the buyer to grant a supplementary period of reasonable duration to deliver the goods. At the expiration of this period he may refuse to accept them, and the contract is ipso facto avoided. This system of dividing remedies according to whether or not time is essential to the contract was developed because of the conditions of international sales contracts which, as far as the United States is concerned, usually involve very long land and/or sea transportation problems; in such cases the contract should continue in force after a sinall delay in delivery, where neither the type of goods nor the contract itself call for special haste. This rule may, of course, be nodified by either a stipulation or a well-known usage of the trade to the contrary. ${ }^{50}$

\section{(b) The Unpaid Seller}

In the case where the seller has not been paid, Umidroit ${ }^{51}$ gives him the choice between suing for the price (if this right is granted him in the place where the action is commenced) and cancelling the contract. The cancellation inust be done immediately if the time of payment was an essential condition of the contract; otherwise, it may be done only after the expiration of a reasonable time. Damages may be obtained even where the contract has been avoided. The Uniform Sales Act inerely allows the unpaid seller to keep the goods, stop delivery by a third person and avoid the contract. 52 The Code, on the other hand, would give such a seller six remedies; and, what is more, it would permit hin to use them all at the same time..$^{53}$ The doctrine of election of remedies has been rejected in the Code. In certain cases this would amount to an arsenal several times larger than that of Unidroit, and an unpaid seller might well do some "forum shopping" before resorting to suit in a Unidroit jurisdiction, although, as explained above, if Undroit were enacted by the United States as a federal statute, it would prevail (with respect to international sales) over the Code as enacted in any particular state. If Unidroit were enacted by most commercially important countries, forum shopping for remedies would be to no avail.

\section{(c) The Problem of Specific Performance}

The Uniform Sales Act grants the power of specific performance to "a court having the powers of equity, if it thinks fit." 54 These words, so re-

ธo Unidroit, Articles 12 and 13.

51 Article 64.

52 Uniform Sales Act $\$ 53$.

53 § 2-703 Commercial Code-Sales. See also \$\$2-709(1) and 7-210 which explain the rather extensive damages allowed an unpaid seller.

54 See Uniform Sales Act $\S 68$. In England this section has been held to permit a court to grant specific performance even where this would be contrary to the former equity jurisprudence. But the case law in the United States has decided that this section is only a "codification of the common law." See 2 Writiston, Sares $\S 601$ (1948). 
strictive to a modern common law court would mean absolutely nothing to a court in a civil code state.

The historical development of specific performance as an extraordinary remedy is not always easily appreciated in countries whose law developed largely out of the Roman law. On continental Europe there is no prerequisite to its use, such as the requirement that the goods be unique or that the award of damages be unjust or insufficient as conpensation in a particular case. According to the laws of these countries specific performance is generally considered a normal remedy which is more or less on a par with others. ${ }^{55}$ The drafters of Unidroit assunied that no complete resolution was possible on this point and they directed their efforts toward the AngloAmerican tradition..$^{56}$ Articles 25 and 26 of Unidroit permit specific performance in favor of the buyer unless this is inpossible or is not permitted by the laws of the jurisdiction where the action is brought. Even in these jurisdictions, the buyer cannot obtain specific performance "where the purchase of such goods elsewhere is in accordance with the usages of the trade or can be made without inconvenience or excessive expense." 57

The Code has followed Unidroit's prescription with regard to umique goods but would also allow specific performance "in other proper circumstances." 58 It would seem to the writer that the words "if it thinks fit" and "other proper circumstances" would not materially differ in restrictive effect from the "usages" found in Unidroit."

55 An example of such a law is Article 1134(3) of the Code Civil Français. See PlaniolRipert, Traité élémentaire du Droit Civil (1943) p. 530; 9 HARv. L. Rev. 78; 22 HARv. L. Rev. 161; Gutteridge, however, has noted that continental case law has recently changed somewhat toward the English solution. "Mr. Troullier, who for several years has been chairman of the Counmercial Court of Paris (tribunal de commerce de la Seine) stated to the committee that in his own experience, it was exceptional to see a suit for specific performance in a contract of sale." Etudes du droit civil a la mémoire de Henri Capitant (1939), pp. 283, 284.

56 Mr. Gutteridge noted that "we cannot entirely equalize these primordially opposite conceptions .... [I]t is clear that Anglo-Saxon countries cannot ever agree with the continent on this poimt. 11 id. at 284.

$57 \mathrm{Dr}$. Rabel has explained that "the draft has made a step toward the Anglo-American system, by providing that even in the continental countries the buyer shall not be entitled to specific performance where it is in accordance with the usage of the trade to repurchase the goods or where he can repurchase them without inconvenience and appreciable expense. Likewise the seller cannot claim payment of the price where a resale is trade usage. These are acknowledgments of a practical advantage of the Anglo-American system. But even this concession has caused misgivings by learned lawyers of a certain European country." Rabel, $A$ Draft of an International Law of Sales, 5 U. OF CFr. L. REv. 543, 560 (1938).

5s § 2-716. Perhaps the change in wording from that of the Uniform Sales Act was made expressly in order that the American courts may follow the English example.

59 There is a difference from the Code with regard to this remedy to be found in Unidroit, Article 29. In a contract where the date of delivery is an essential condition, the buyer cannot maintain specific performance "unless he has notified the seller to that effect without undue delay after he has ascertained the delay in delivery ...." \$2-711(2) of the Code permits the buyer to obtain specific performance "in a proper case" without such notice if the seller has not delivered the goods. 


\section{(d) Damages}

As with the question of specific performance, the drafters of Unidroit leaned toward the Anglo-American viewpoint in formulating rules on damages. Article 85 states:

Where the contract is not cancelled, damages shall be equal to the loss actually suffered and the loss of profit. However, these damages thus calculated shall not be in excess of the damage resulting from those events which the party liable therefore knew or was bound to take into consideration at the time of the conclusion of the contract.

These words represent an attempt to approach the English rule first stated in the case of Hadley $v$. Baxendale which is now well imbedded in the law of the United States. ${ }^{60}$ The drafters had less difficulty in achieving unity by adopting this rule for it is of ancient origin in continental Europe. ${ }^{61}$ The Code has followed the words of Unidroit very closely here; however, the rule was not made to depend on the question of cancellation of the contract as in Article 85 and 89 Unidroit. $^{62}$

609 Exch. 341 (1854). This rule was followed by the Supreme Court in Globe Refining Co. v. Landa Cotton Oil Co., 190 U.S. 540 (1903). It has also been incorporated in the RestaTEAIENT, ConTracts $\$ 330$ (1932). See $\$ \$ 67,64(2), 69(6)$ and $69(7)$ of the Uniform Sales Act. The result is clearer in the sections on breach of warranty, $\$ \$ 69(6)$ and $69(7)$ than in the sections on non-delivery. However, $\$ 70$ indicates that the case law must be regarded in this matter.

61 In Planiol-Ripert, Traité élémentaire de Droit Civil (1943), p. 530 words are used to express the French rule closely resembling those of the American statute:

"By only looking at what actually follows execution, you can see two types of damages: those which naturally and ordinarily could have been foreseen by the obhgor and those which he could not have foreseen. In any case the obligor should pay damages which he foresaw or could have foreseen at the time the contract was enacted."

According to Planiol, this rule is derived from a constitution of Justinian (Code, 7, 47, of the single law). The Emperor limited to double the amount of damages in the case of a contract wherein the quantity and quality of the obhigations were certain. This origin of the rule seems rather dubious but it entered the French Civil Code of 1804 (Article 1150) from the treatise of Pothier, which was the greatest source for the drafters of that Code. See A. Dumas, Les origines romaines de l'article II50 du Code Civil, Melanges Girard (1912), p.95. It seems to this writer that a better explanation for the rule inay be found in the digest of Justinian, XIX.I de Actionibus Empt Uenditi. In stating that there is no action for the value of slaves who died of famine following non-delivery of a quantity of wheat bought by a plaintiff it has been noted that compensation is due only for such losses as the party in default foresaw, or might by the exercise of reasonable prudence have anticipated, as the direct result of his delay. See Mackintosh, The Romin Law of Sale 191 (1907).

02 \& 2-715 (2) states that "consequential damages include (a) any loss resulting from general or particular requirements and needs of which the seller at the time of contracting had reason to know and which could not reasonably be prevented by cover or otherwise; and (b) injury to person or property proximately resulting from any breach of warranty." (See Unidroit, Article 47 in connection with $\$ 2-715(2)(b))$. As with the Uniform Sales Act, the Code refers to the case law in this matter in its \$2-714 entitled "Buyer's Damages for Breach in Regard to Accepted Goods.... (3) in a proper case any incidental and consequential damages under the next section may also be recovered." (Italics added). 


\section{Seller's Damages for Non-acceptance}

In the Uniform Sales Act and in both the international and domestic projects, damages for non-acceptance are equal to the difference between the contract price and the current market price of the goods. ${ }^{.3}$ However, in the Code the recovery of damages is not tied to a cancellation of the contract; cancellation is only one of several remedies available at the choice of the complaining party. ${ }^{64}$

The "market price" established by Unidroit is that "current on the day following that on which the right to cancel has been exercised or upon which the contract was ipso facto avoided." In the Code that price is established "at the time and place for tender"; and, in the Uniform Sales Act it is fixed "at the tinie or times when the goods ought to have been accepted, or, if no time was fixed for acceptance, then at the time of the refusal to accept." In most cases this day will be the same in the statute and in both projects. However, if the delivery date is not an essential condition of the contract, the current or niarket price may be determined on a later day in Unidroit than with the Code. ${ }^{65}$ Here the Code is more precise. In both projects the special expenses of the seller are reimbursed. ${ }^{60}$

\section{Buyer's Damages for Non-delivery}

In Unidroit and the Uniforn Sales Act the damage rules are the same where the goods are not accepted as in the case of non-delivery. ${ }^{07} \mathrm{But}$, Section 2-713 of the Code states that the measure of damages for nondelivery "is the difference between the price current at the time the buyer learned of the breach and the contract price ...." This period could, of course, be nuch longer than "the further reasonable period of time" which, under Article 29 of Unidroit, discussed above, the seller may demand for delivery in a contract where time of delivery is not of the essence.

\section{When a Current Market Price Does Not Exist}

The Uniforn Sales Act offers no standards when the market price cannot be determined readily. The Code, searching for the nearest substitute

63 Unidroit, Article 87; Uniform Sales Act $\$$ 64.3.

$04 \$ \$ 2-703,2-708$ and 2-711, Commercial Code-Sales.

65 See Unidroit, Article 29; see discussion on Delay in Delivery, text supra at note 47.

66 Here again the seller may receive more with the Code than with Unidroit. Article 87 of the latter states that "the normal expenses of purchasing or selling the goods elsewhere shall also be taken into account" where the contract has been avoided. The Code would grant the seller incidental danages ( $\$ 2-710)$ which it describes as "any commercially reasonable charges, expenses or commissions incurred in stopping delivery, in the transportation, care and custody of goods after the buyer's breach, in connection with return or resale of the goods or otherwise."

or Unidroit, Article 87; Uniform Sales Act $\$ \$ 67(3)$ and 64(3). 
refers to the

price prevailing within any reasonable time before or after the time described or at any other place which in commercial judgment or under usage of trade would serve as a reasonable substitute for the one described may be used, making any proper allowance for the cost of transporting the goods to or from such other place .... ${ }^{6 s}$

This is detailed and all-inclusive. The section is probably an improvement over Unidroit's substitute for a current price which entirely abandons the idea of a market price and determines the damages according to the "loss actually suffered (including loss of profit) of the party who cancelled the contract." In spite of the fact that these damages are limited and cannot be in excess of what should have been foreseen by the other party, ${ }^{69}$ America would perhaps prefer a damage rule which referred to the price on a more distant market than one which allows greater leeway for a jury judgment. On the other hand, if the goods are unique, Unidroit's rule becomes a necessity. ${ }^{\mathbf{7 0}}$

\section{Warranties}

Section 15(2) of the Uniform Sales Act states that "there is an implied warranty that the goods shall be of a merchantable quality" in the case of a sale by description. The Code continues this warranty but limits its application to "nierchants"71 and it then defines "merchantable" to mean, in part, goods which "pass without objection in the trade... [and] are of fair average quality in the trade ...."T2 This broadening change from the Uniform Sales Act tends toward existing law of the civil law countries whose warranties have been traditionally larger than those of the Anglo-Americans. In civil law countries goods may be warranted for what might be called "normal usage." ${ }^{73}$ Such an implied warranty is to be found in only two of the states of the United States. ${ }^{74}$ In Unidroit, these two warranties are combined and the seller must warrant both normal usage and merchantable quality. ${ }^{75}$

\section{Application and Usage}

The Code and Unidroit have been drawn up with entirely different points of view concerning the application of each article. According to Articles 12 and 13 of Umidroit, the entire project is subject to the exception

$68 \S 2-723(2)$.

69 Unidroit, Article 90.

70 Because both rules are complementary, it would seem that they could both be employed in a particular sales statute.

$71 \S 2-314(1)$.

$72 \& 2-314(2)$.

73 For example, Articles 1641-1643 of the French Civil Code.

74 Louisiana and South Carolina.

75 See Unidroit, Article 37. 
of contrary usage or expression of the parties. However, if by a clause to that effect the parties exclude the application of Unidroit from their contract, they must expressly designate the law of one country or other specific rules which will apply. The Code, on the contrary, originally stated that its rules are "mandatory and may not be waived or modified by agreement unless the rule is qualified by the words 'unless otherwise agreed' or their equivalent." ${ }^{76}$ The great majority of the sections including those concerning the formation, performance and breach of the contract and half of the rules on the construction of the contract would not have been generally subject to derogation by the parties although, fortunately, the very strong sections concerning remedies could have been substituted for by the buyer and seller. ${ }^{77}$

The mandatory character of the Code before revision left little room for an unexpressed intention of the parties even though it be evidenced by usage. The Code was revised in order to indicate that only general obligations "such as good faith, due diligence, commercial reasonableness" may not be disclaimed by agreements; and, in general, all other provisions of the Code may be varied by agreement. ${ }^{78}$ Further, the Code provides that "the parties to a contract are bound by any course of dealing between them and by any usage of trade of which both are or should be aware."70 The new approach is clearly in the direction of the traditional position of the civil law countries based upon freedom of contract and a devotion to usage.

Unidroit follows this tradition; however, it provides for some identification of controlling usage by permitting modifications of all its articles by usages which are tacitly "referred to." 80

\section{CONCLUSION}

The field of international sales has been one of the strongest fields of so-called "adhesion" contracts. Indeed, this reality at first forced the drafters of Unidroit to consider whether or not these forms might be a better basis for the international draft than the laws and jurisprudence in force in the principal trading countries. It was only the complete anarchy reign-

76 \& 1-107 (1949 tentative final draft).

77 Id. \& 2-721.

$78 \S 1-101$ (2) (c) and (d). The meaning of the words "unless otherwise agrced" which qualify many provisions of the Code remains somewhat obscure since, in gencral, any provisions may be modified by agreenent-even in the absence of such qualifying words. See $\S 1-102(3)$ (d).

$79 \S 1-205$ (3). This is a requirement under existing law. Thus, for example, the California decisions have required that the custoin or usage be known either specifically or by implication. Miller v. Germain Seed Co., 193 Cal. 62, 222 Pac. 817 (1924) ; Latta v. Da Rosa, 100 Cal. App. 606, 607, 280 Pac. 711, 281 Pac. 655 (1929), rehearing denied per curiam; Robertson v. Dodson, 54 Cal.App.2d 661, 129 P.2d 726 (1942).

80 See Umidroit, Article 13. 
ing in the forms, which differ greatly from industry to industry, that turned them away. ${ }^{81}$ Their aim was to unify international usages and conflict rules on sales contracts. For this purpose form-contracts were found to be of limited value. ${ }^{82}$

Resolving the various sales laws became a problem of resolving the various system of sale laws such as those on the European continent as well as the Scandinavian and Anglo-American systems, which differ in the organization of their provisions as well as in the substantive law contained in these provisions. This attempt, the first of its kind, may well be worth the experience as a statute because a unification of the private laws of the world will be started between common law and civil law countries. It will have been commenced with a statute on one branch of law where agreement is at a maximum and thus success is less difficult of attainment than in most other fields of law. We have attempted to show how the fundamental questions in a sale (such as those concerming delivery and risk of loss) do not differ in substance from system to system; although the contrary view is widely believed because of the different fashions in which these concepts are expressed in the various sales laws. The new Uniform Commercial Code-Sales expresses these concepts in a more extensive and thorough (if more complex) manner than does the Uniform Sales Act. However, such legal problems in the field of international trade cannot be solved by any enactment in a single country. "No American Code . . . can have extraterritorial force." 83 In the field of foreign trade we must look toward a single law governing the international sale of goods which can have such force. In Unidroit, we have a well-considered uniform law which has been drafted to attain this result.

81 See 1 tetudes du droit civil a la memoire de Henri Capitant 274 (1939), where Gutteridge pointed out that: "The isolated merchant who does not belong to a large commercial organism generally does not use this type of contract and consequently, one imagines that there are a large number of international transactions which are outside the domain of standard forms."

82 Id. at 137; see also The Conflict of Laws, A Comparative Study 482 (1947) wherein Dr. Rabel made the following plea: "[W]e need a developed system of conflicts rules on contracts, rather than just one or two rules, and we have to build it not on rules so vague as to abandon the judge regularly to his worry or fancy, nor on specifications so tight as to omit important kinds of agreements. This program requires comparative research in the mumicipal law and in commercial practice with respect to each single type of contract, a work so far only partially started.

"Experience, however, seems to show that commerce is served by a number of standard forms, with newly devised clauses rapidly imitated throughout the world. In the vast domain of sales of goods, differences in stipulations are caused much more often by the natural differences of merchandise sold than by local or national predilection. Insurance, banking carriage of goods contracts may be distinguished in analogous groups under rational rather than local criteria. For this and other reasons, it may be less difficult than appears at first sight to resolve the local attachments most characteristic of the individual groups of contracts."

83 Williston, The Law of Sales in the Proposed Uniform Commercial Code, 63 Harv. L. REv. 561, 563 (1950). 